\title{
The Development of Curriculum Implementation Model Merdeka Belajar at Engineering Faculty
}

\author{
$1^{\text {st }}$ Harun Sitompul ${ }^{1}, 2^{\text {nd }}$ Zulkifli Matondang ${ }^{2}, 3^{\text {rd }}$ Eka Daryanto $^{3}, 4^{\text {th }}$ Sapitri Januariyansah $^{4}$ \\ \{prof_runsit@yahoo.co.id ${ }^{1}$, zulkiflimato@gmail.com ${ }^{2}$, ekadaryanto@unimed.ac.id ${ }^{3}$, \\ sapitrijanuariyansah@unimed.ac.id $\left.{ }^{4}\right\}$ \\ Civil Engineering Education, Engineering Faculty ${ }^{1,2}$, Automotive Engineering Education, \\ Engineering Faculty ${ }^{3}$, Mechanical Engineering Education, Engineering Faculty ${ }^{4}$, \\ Universitas Negeri Medan
}

\begin{abstract}
This study aims to develop guidelines for implementing the Merdeka Belajar (MB) curriculum at the Faculty of Engineering Unimed. There are eight types of learning in the implementation of the $\mathrm{MB}$ curriculum, namely: internships/work practices, teaching in education units, implementing humanitarian projects, research, entrepreneurial activities, independent studies/projects, student exchanges and village development/Thematic Community Service Programs. Through the implementation of a good and appropriate IL curriculum, it will produce graduates who are superior, professional, with character and have intellectual intelligence, skills, entrepreneurship and have a national perspective. This type of research was development research. The development of the IL curriculum implementation model was carried out in 7 of the 10 steps outlined by Bold and Gall. The sources of data in the research were the head of study programs, curriculum experts, media experts, and study program partners. The development carried out in the research was the implementation of the IL curriculum with learning management system (LMS) facilities. This study resulted in a guide, facilities and learning media in the form of LMS in the implementation of the IL curriculum at Faculty of Engineering Unimed. The results of the validation test on the IL implementation guidelines and LMS can be categorized as valid (valid) so that it can be used by students of Engineering Faculty Unimed. The results of the LMS quality display test for the implementation of the IL curriculum at Faculty of Engineering Unimed obtained good category results. There are several aspects that have been improved on the developed LMS. The development of the IL curriculum implementation model at Engineering Faculty Unimed can be used in learning. The implementation of the IL curriculum can be carried out properly if it has proper guidelines and LMS. The implementation and measurement of student competencies who follow the IL curriculum will be measured more accurately and reliably. In the end can improve the competence of Engineering Faculty Unimed graduates.
\end{abstract}

Keywords: Development, curriculum, merdeka belajar, LMS

\section{Introduction}

Currently, the students face changes in social, cultural, world of work and rapid technological advances. For this reason, the student competencies must be prepared to suit 
the needs and developments of the times. The changing times are so fast and dynamic, that every educational institution is required to design and implement innovative learning processes. The Faculty of Engineering is one of the faculties at Universitas Negeri Medan (Unimed) to produce graduates who have competencies according to the needs and changing times. In producing competent graduates, The Faculty of Engineering Unimed participates by changing and implementing the KKNI curriculum based on merdeka belajar (MB). The Freedom of Learning Policy at Faculty of Engineering Unimed is expected to be one of the answers to the demands of changing times. Kampus merdeka $(\mathrm{KM})$ is a form of learning in higher education that is autonomous and flexible so as to create a learning culture that is innovative, unfettered, and in accordance with the needs of students.

Merdeka belajar Program at Faculty of Engineering Unimed is carried out by giving the right to study for three semesters outside the study program. The students are given the freedom to take credits outside the study program for three semesters, consisting of 1 semester of opportunity to take courses outside the study program and 2 semesters of carrying out learning activities outside the study program. Merdeka belajar Policy is a learning innovation framework that aims to provide broad opportunities for students to develop creativity, capacity, personality, and student needs, as well as develop independence in seeking and finding knowledge through realities and field dynamics. The study program is no longer the only place for students to study, because apart from being given the opportunity to study across study programs, across faculties and across universities, students can also take learning activities outside the study program where students are directly involved in solving real problems, social interaction, collaboration, self-management, achieving targets and realizing projects/ideas/ideas in the field.

The various forms of learning activities that can be carried out outside the study program, including: conducting internships/work practices in industry or other workplaces, implementing community service projects in villages, teaching in educational units, participating in student exchanges, conducting research, conducting entrepreneurial activities, make independent studies/projects, and participate in humanitarian programs. All learning activities outside the study program must be carried out with guidance from the lecturer and known by the head of the study program. Kampus merdeka is expected to provide field contextual experiences that will improve student competence as a whole, be ready to work, or create new jobs.

The implementation of the merdeka belajar program at Faculty of Engineering Unimed in 2019/2020 in the form of student exchanges through the Permatasakti and Permatasari programs. To carry out the merdeka belajar program to run well, various rules and guidelines are prepared so that the program can run as expected. Some of the weaknesses of implementing merdeka belajar in student exchange activities, including: 1) difficulty in choosing courses taken outside the study program, 2) The student exchange implementation system does not have the same schedule between study programs or between universities, 3) Place (study program) the reference does not provide courses and credits that are as expected, 4) the lecture system, assignment and assessment of each subject is not the same or similar between the study program (college), 5) the administrative system (student exchange registration) is not maximized, and 6 ) students do not understand the advantages and benefits of implementing the student exchange. 
Likewise, with other learning activities outside the study program, such as internships, teaching in educational units, carrying out community service projects, carrying out research, entrepreneurial activities and participating in humanitarian programs, All learning activities outside the study program are still general in nature so it is necessary to develop a guideline or standard so that the implementation of the merdeka belajar program can be implemented and measured properly.

The Minister of Education and Culture's policy regarding the merdeka belajar program was followed up with the Unimed Chancellor's Decree Number 362 of 2020 concerning the Implementation of Free Learning at the State University of Medan. Based on the Decree of the Chancellor of Unimed, each study program at Faculty of Engineering Unimed prepares the IQF curriculum by implementing merdeka belajar (MB). In the structure of the study program curriculum at Faculty of Engineering Unimed, there are several courses that can be implemented in implementing the MB policy. The process of preparing the MB curriculum in each Faculty of Engineering Unimed study program, reviews the learning outcomes (Learning Outcomes) of each subject that can be carried out by learning activities outside the study program. Review of learning achievements is carried out so that students of each study program at Faculty of Engineering Unimed have a broader and concrete learning experience and have new competencies that are measurable (valid) according to current and future market needs.

In order to develop curriculum in each study program, a basic framework is needed to provide direction and signs in developing the curriculum of the study program. It is intended that the curriculum developed is in accordance with the vision and mission of study programs, faculties, universities and in accordance with national education goals. In addition, the basic framework for developing this curriculum can be used as a reference in evaluation or academic quality assurance efforts within the Faculty of Engineering Unimed environment. Each study program at Faculty of Engineering Unimed continues to review and revise the curriculum according to technological developments. The KKNIbased curriculum is an embodiment of the quality/competence and identity of graduates from study programs at Faculty of Engineering Unimed that are in accordance with market needs (Schools and industry).

Based on the KKNI-based curriculum in the Faculty of Engineering Unimed study program, there are several courses that contain competencies (learning outcomes) that can be implemented in implementing the MBKM policy made by the Indonesian Minister of Education and Culture. Based on the distribution of courses in the Faculty of Engineering Unimed study program, there are several types of learning activities that can be carried out in implementing MBKM, namely: student exchanges, internships/practice work, research, entrepreneurial activities and teaching assistants in education units as well as real work lectures in the community. In the context of implementing MBKM in the Faculty of Engineering Unimed study program, it is necessary to review the learning outcomes (Learning Outcomes) of each subject that can be carried out by learning activities outside the study program.

To find out the needs of the community, a survey or hearing from stakeholders is carried out. Meanwhile, to find out the needs of the profession, consultation between similar educational institutions and analysis of professional job descriptions were carried out. Professional needs are developed by taking into account the needs of the profession in the next 10 years. Curriculum development methods include the following: (1) 
Identification of educational goals to be achieved through the curriculum; (2) Description of educational program outcomes in the form of graduates' abilities, knowledge, and expertise; (3) Efficient development of curriculum and syllabus/GBPP; (4) Considering stakeholder needs; (5) Taking into account the existing resources for the implementation of the teaching and learning process; (6) The scope of knowledge provided is in accordance with the structure of the field of study; and (7) There is a procedure for evaluating and improving the curriculum on a regular basis

Good curriculum development is obtained through good development stages, too. The stages of developing the study program curriculum at the Faculty of Engineering Unimed is as shown in Figure 1.

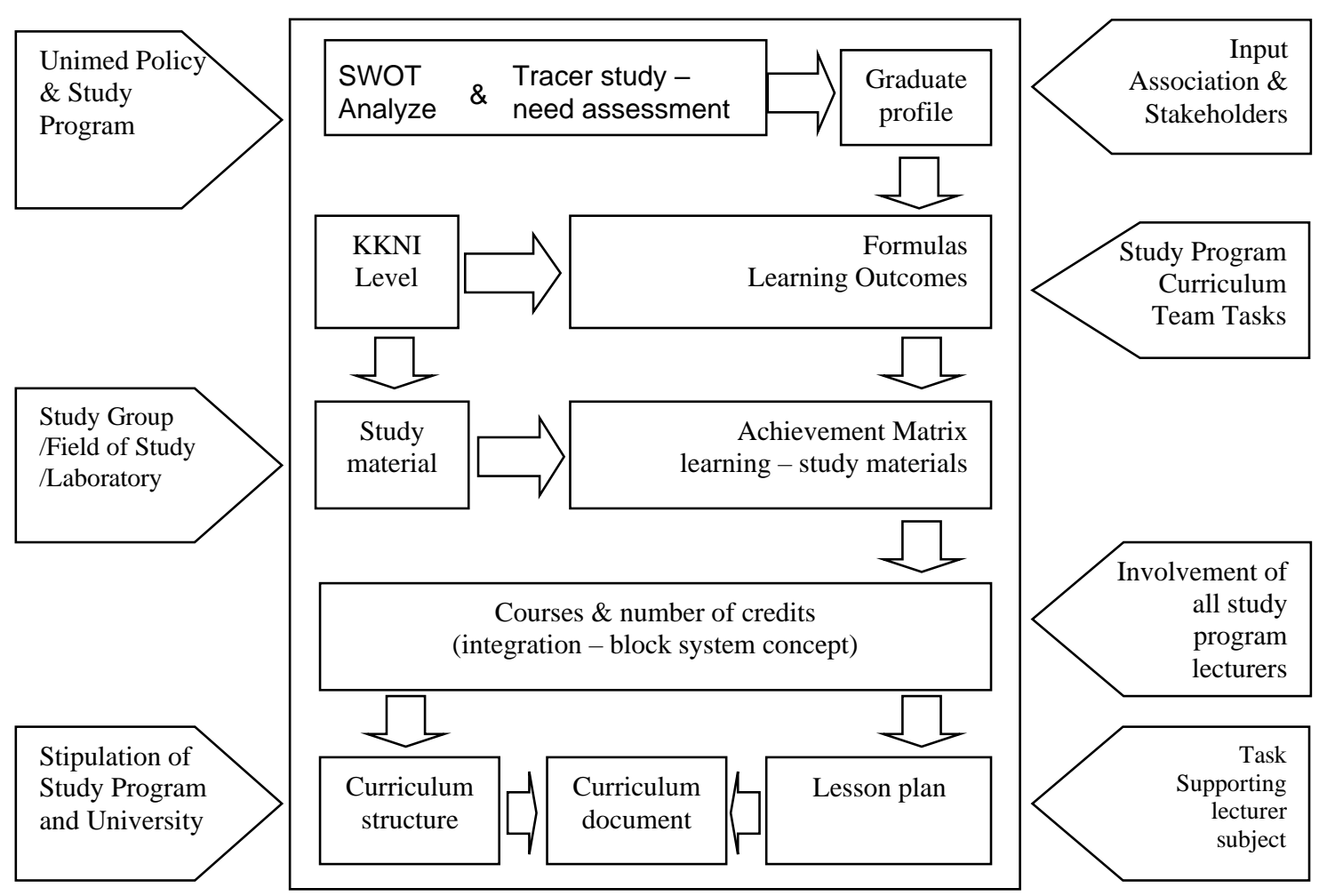

Fig. 1. Stages of study program curriculum development.

In developing the curriculum of the study program at the Faculty of Engineering Unimed, it is based on the principles of curriculum development as follows: 1) Relevance, the curriculum developed must be related to the field of science, relevant to the development of science and technology, socio-economics, and community needs, both today and in the future. future. 2) Continuity, the curriculum developed must have continuity between sections of disciplines and between levels of education, both with the previous level and with the next level. 3) Flexibility, the curriculum developed should be able to bridge the gap between graduates and the world of work. 4) Effective and efficient, the development and implementation of the curriculum must consider the available resources, both physical 
resources and human resources, and utilize them optimally so that their implementation can be effective and efficient to achieve the goals that have been set.

In line with the development of technology and industry, the curriculum of an educational institution needs to be adjusted. The Minister of Education and Culture of the Republic of Indonesia (Mendikbud RI) enacted a new policy in the field of higher education through the "Merdeka Belajar-Kampus Merdeka (MBKM)" program. This policy strengthens the link and match between study program graduates at Faculty of Engineering Unimed and Industry as well as the speed of anticipating changes in the future. The implication of this policy relates to the granting of freedom for students to participate in learning a maximum of three semesters of study outside the study program at Faculty of Engineering Unimed.

The MBKM policy provides opportunities for students of each study program at Faculty of Engineering Unimed to gain a wider learning experience and new competencies through several learning activities including student exchanges, internships/work practices, research, independent projects, entrepreneurial activities, humanitarian projects, teaching assistance in units. education, and projects in villages/college thematic real work. In addition, students of each study program at Faculty of Engineering Unimed are also given the freedom to participate in learning activities outside their study program in the same university with a certain credit weight.

Various forms of learning activities outside the study program or outside universities, including doing internships/work practices in industry or other workplaces, carrying out community service projects in villages, teaching in educational units, participating in student exchanges, conducting research, conducting activities entrepreneurship, making independent studies/projects, and participating in humanitarian programs. All these activities must be carried out with the guidance of the lecturer. Kampus merdeka are expected to be able to provide field contextual experiences that will improve student competencies as a whole, be ready to work, or create new jobs.

The learning process in the implementation of the kampus merdeka is one of the very essential manifestations of student-centered learning. The implementation of merdeka belajar provides challenges and opportunities for students to develop innovation, creativity, capacity, personality, and student needs, as well as develop independence in seeking and finding knowledge through realities and field dynamics such as ability requirements, real problems, social interaction, collaboration, self-management, performance demands, targets and achievements. Through an merdeka belajar program that is well designed and implemented, students' hard and soft skills will be formed strongly.

The implementation of merdeka belajar contextually is in line with the conception of education according to Ki Hajar Dewantara. According to Sesfao, Ki Hadjar Dewantara's conception of education still has relevance in the context of contemporary Indonesian education [1]. Relevant in the level of discourse and contextual reality of education in Indonesia today. Although Ki Hadjar Dewantara lived during the independence movement until the beginning of Indonesia's independence, his educational discourse is still able to answer the problems of education today. According to Ki Hadjar Dewantara, education is an effort to promote the growth of character (inner strength, character), mind (intellect) and the child's body, in the context of the perfection of life and harmony with the world [2]. In other words, education forms people who are virtuous, think (smart, intelligent) and have a healthy body.

Currently, creativity and innovation are important keywords to ensure Indonesia's sustainable development. Students who are currently studying in higher education institutions must be prepared to become real learners who are skilled, flexible and tenacious (agile 
learners). Humanist education with the aim of liberating each individual is an educational concept proposed by Ki Hadjar Dewantara. The implication of this concept of education is seen as education that must reach the culmination point where it is able to bring humans to be independent physically and mentally (human totality). The dialogical method is considered very suitable for use in the educational process.

The MBKM Policy launched by the Minister of Education and Culture is a framework to prepare students to become strong scholars, relevant to the needs of the times, and ready to become leaders with a high national spirit. Permendikbud No. 3 of 2020 gives students the right to study 3 semesters outside their study program. Through this program, there are wide opportunities for students to enrich and improve their insights and competencies in the real world in accordance with their passions and ideals. We believe that learning can happen anywhere, the universe of learning is limitless, not only in classrooms, libraries and laboratories, but also in villages, industries, workplaces, places of service, research centers, and in the community. Through close interaction between universities and the world of work, with the real world, universities will be present as a spring for the progress and development of the nation, directly contributing to the coloring of the nation's culture and civilization.

Merdeka belajar program answers the challenges of higher education to produce graduates who are in accordance with the times, advances in science and technology, the demands of the business and industrial world, as well as the dynamics of society. The objective of the merdeka belajar policy "students' right to study for three semesters outside the study program" is to improve the competence of graduates, both soft skills and hard skills, to be more prepared and relevant to the needs of the times, to prepare graduates as future leaders of the nation with excellent and personality. Experiential learning programs with flexible pathways are expected to facilitate students to develop their potential according to their passions and talents.

The implementation of merdeka belajar will involve a number of parties, including universities (PT), faculties, study programs, students, and partners. For PT managers, it is obligatory to facilitate the rights for students (can be taken or not) to: (a) be able to take credits outside of tertiary institutions for a maximum of 2 semesters or equivalent to 40 credits and (b) can take credits in different study programs at universities the same height as much as 1 semester or equivalent to 20 credits. In order to implement merdeka belajar, the faculty should: (a) prepare facilitation of a list of faculty-level courses that students can take across study programs and (b) prepare documents for collaboration with relevant partners.

The study program (study program) should: (a) compile or adapt the curriculum to the implementation model of kampus merdeka, (b) facilitate students who will take cross-study learning within PT, (c) offer courses that can be taken by students outside the study program. and outside the PT and its requirements, (d) conduct the equivalence of courses with learning activities outside the study program and outside the PT, and (e) if there are courses/credits that have not been fulfilled from learning activities outside the study program and outside the PT, alternative online courses are prepared.

For students in implementing merdeka belajar, they must: (a) plan with their academic supervisor to identify courses/programs that will be taken outside the study program, (b) register for activities outside the study program, (c) complete the requirements for activities outside the study program, including participating in the selection process. if any, and (d) participate in a program of activities outside the study program in accordance with the provisions of the existing academic guidelines. Finally, for partners, they must (a) make a cooperation document with a university/faculty/study program and (b) carry out an activity program outside the study program in accordance with the provisions contained in the cooperation document. 
To be able to run well the implementation of merdeka belajar, it is necessary to develop a guideline so that the program is successful in achieving its goals. In compiling a guideline, appropriate steps or procedures are needed, so that the guideline contains all the things that can regulate the implementation of merdeka belajar activities, especially at the study program level.

Research and development activities or Research and Development (R\&D) is a research method used to produce products (in the form of free learning implementation guidelines) and test the effectiveness of these products [3]. The model used in this study is the Borg and Gall model.

The R\&D research method seeks to produce or develop a product (guideline) whose results can be justified. Guidelines for the implementation of merdeka belajar are developed based on the results of theoretical studies, observations, interviews and so on. The development of a product (guidelines) can generally be grouped into three procedures, namely product development models, product development procedures, and product trials.

There are ten steps of the development model proposed by Borg and Gall, namely as follows: 1) Initial data collection (research and information); 2) Planning (planning); 3) Development of a product draft (develop a preliminary form of product); 4) Initial field testing (preliminary field testing); 5) Revision of product trial results (main product revision); 6) Field testing (main field testing); 7) Completion of the results of field trials (operational product revision); 8) Field testing (main field testing); 9) Product improvement (final product revision), and 10) Dessemination and implementation [4]. Based on the ten steps developed by Borg and Gall in this study, the implementation only reached the seventh step.

\section{Method}

The research location was at Faculty of Engineering Unimed and conducted in MayAugust 2021. This type of research was research and development (R\&D). The stages and procedures of development research referred to the opinion of Borg and Gall, namely: "research and information collecting, planning, developing preliminary form of product, preliminary field testing, main product revision, main field testing, operational product revision, operational field testing, final product revision, and dissemination and implementation". Based on the ten steps developed by Borg and Gall, in this study the implementation reached the seventh step [4]. This was done due to the limitations of the researcher, both in terms of time and ability. The results or impacts of the application of the model already exist, both in limited tests and wider trials because during the implementation of learning there are tasks that students carry out and tests are also carried out. Researchers only adopted seven steps out of ten research steps according to Borg and Gall.

The development of guidelines is used to implement merdeka belajar for Faculty of Engineering Unimed students. Through the development of merdeka belajar guidelines, so that its implementation will be able to run well and can improve student competence.

The data to be obtained in this study are in the form of qualitative and quantitative data. Qualitative data in the form of information about the process and implementation of merdeka belajar in each study program at Faculty of Engineering Unimed, such as the administrative process in implementing merdeka belajar: student exchange, courses offered in the implementation of merdeka belajar, becoming a teacher assistant (teaching in education units), internships/work practices on DUDI, doing entrepreneurship and others. Quantitative 
data in the form of descriptive information about the number of study partners (schools, DUDI, other universities, SMEs, etc.) as well as validation tests by experts.

The subjects and sources of data in this study were all people and agencies involved in the implementation of merdeka belajar at Faculty of Engineering Unimed. The research subjects are the head of the study program, the head of the department, students, supervisors, and the study program partners (schools, DUDI and other agencies). To obtain data from research subjects, several methods and data collection tools were used. The research data collection methods were carried out such as observation, interviews and questionnaires. Analysis of the data used is a validation test from experts on the product being developed. Expert validation carried out is content validation and validation of the developed LMS product. The results of expert validation are categorized in making conclusions. Sequentially these steps can be made a chart as shown in Figure 2.



Fig 2. Steps in the preparation of the MB curriculum LMS. 


\section{Results and Discussion}

The initial step carried out in this research is an analysis of the need for developing an MB implementation model on Faculty of Engineering Unimed. The results of the FGD and interviews with the informants and respondents concluded that it is necessary to develop a model for implementing MB in Faculty of Engineering Unimed. The development of this model is so that the implementation of $\mathrm{MB}$ among study programs in the Faculty of Engineering Unimed environment is more systematic and measurable in accordance with the learning objectives. In developing the MB learning model, it refers to the nature of accessibility, informative, effective, and efficient. Furthermore, the FGD results received input so that the system form and the conversion of the results of MB activities need to be well designed so that the MB activity process can be monitored and measured accurately. Another thing that is important is to strengthen cooperation between study programs in the Faculty of Engineering Unimed environment.

The planning of the MB Faculty of Engineering Unimed implementation model is designed with an easy-to-use access system. Two stages are carried out by students to take part in MB learning at Faculty of Engineering Unimed. The first step is to register on the web mbkm-ft-unimed.org. On the MBKM Faculty of Engineering Unimed website, a description of each activity from the implementation of $\mathrm{MB}$ is presented. The contents of the description of each type of MB activity include an introduction to the activity, the objectives of the activity, requirements, procedures for implementation, and the form of the activity. On the same page, also provide an online registration form that students can directly access online. The registration form is the initial data that is a prerequisite to be able to join the implementation of MB Faculty of Engineering Unimed through learning management system (LMS). The LMS used in the implementation of MB Faculty of Engineering Unimed is Moodle. There are 8 types of activities offered to students in the MB implementation, namely: (1) Student Internships; (2) Thematic Community Service Program; (3) Humanitarian Projects; (4) Entrepreneurial Activities; (5) Independent Study/Project; (6) Research/Research; (7) Student Exchange; and (8) Teaching in Schools. The LMS can be accessed via the following page: mbkm-ft-unimed.org/portal. Each activity will be grouped based on each study program at Faculty of Engineering Unimed. Students who have registered on the mbkm$\mathrm{ft}$-unimed.org website will be given a special LMS code. The Head of Study Program at Faculty of Engineering Unimed will be given access to create a Companion Lecturer as an implementing assistant. The LMS of registration MBKM Faculty of Engineering Unimed can be seen in Figure 3. 




Fig. 3. LMS registration for MBKM.

The results of the development of the MB Faculty of Engineering Unimed curriculum implementation model refer to the design from the Ministry of Education and Research and Technology which includes 8 types of activities. Of the 8 types of MB activities developed at Faculty of Engineering Unimed, they are presented on a website with the name LMS, namely mbkm-ft-unimed.com. The general appearance of the website for the implementation of the merdeka belajar of Faculty of Engineering Unimed is presented in Figure 4.



Fig. 4. Website for the implementation of MBKM.

The assessment system used in the implementation of MB Faculty of Engineering Unimed includes self-assessment, peer-assessment, teacher/field supervisor assessment, and assessment of accompanying lecturers. This scoring system is carried out to obtain reliable results which in short are objective results. Students who are registered at mbkm-ftunimed.org/portal are required to do the tasks given in the LMS such as initial reports, weekly reports, daily logbooks, and final reports. Another thing that was also carried out was sharing 
sessions between students and accompanying lecturers as a form of monitoring activities. All of this can be easily accessed through the website and the LMS that has been designed.

At the validation stage, the MB curriculum development model was asked for the opinion of experts in providing input on the model. The results of expert opinions on the contents of the LMS model for implementing the MB curriculum are as shown in Table 1.

Table 1. Average LMS validity test results for the implementation of MBKM.

\begin{tabular}{llcccccc}
\hline \multirow{2}{*}{ No } & \multirow{2}{*}{ Type of Activity FL } & \multicolumn{5}{c}{ Assessment Aspect (Average) } \\
\cline { 3 - 7 } & $\begin{array}{l}\text { Selft } \\
\text { Intruction }\end{array}$ & $\begin{array}{l}\text { Self } \\
\text { Contined }\end{array}$ & $\begin{array}{l}\text { Stand } \\
\text { Alone }\end{array}$ & Adaftive & $\begin{array}{l}\text { User } \\
\text { Friendly }\end{array}$ & \\
\hline 1 & Internship & 4.2 & 4.1 & 4.3 & 4.0 & 4.2 & 4.2 \\
2 & Thematic Com. Service Program & 4.0 & 3.9 & 3.8 & 4.0 & 4.1 & 4.0 \\
3 & Humanitarian Projects & 4.1 & 3.7 & 3.5 & 3.9 & 3.8 & 3.8 \\
4 & Entrepreneurial Activity & 4.2 & 3.8 & 3.7 & 3.6 & 3.9 & 3.8 \\
5 & Independent Study & 3.9 & 3.5 & 3.5 & 3.6 & 3.8 & 3.7 \\
6 & Research & 3.6 & 3.2 & 3.4 & 3.5 & 3.8 & 3.5 \\
7 & Student Exchange & 3.9 & 3.8 & 3.8 & 3.9 & 4.0 & 3.9 \\
8 & Teaching in School & 4.2 & 4.2 & 4.2 & 4.0 & 4.3 & 4.2 \\
\hline & Average & 4.0 & 3.8 & 3.8 & 3.8 & 4.0 & 3.9 \\
\hline
\end{tabular}

Based on Table 1 shows that the data and information about the results of the LMS validation of the implementation of the MB Faculty of Engineering Unimed curriculum. In general, the quality of the LMS for MB activities in the type of internship and teaching in schools has the best quality with an average score of 4.2. The quality of the LMS implementation with the lowest score is research activity with a score of 3.5. The results of the validation of the LMS quality of each merdeka belajar activity are presented in Table 1 . The LMS quality assessment developed for the implementation of MB in Faculty of Engineering Unimed is based on 5 aspects. Judging from the average assessment results for each aspect, the quality of the LMS developed was higher in the self-instruction and user-frendly aspects with a score of 4.0. While the other three aspects of the assessment such as self-continued, stand-alone and adaptive have the same score of 3.8. Thus, based on the validation results, the LMS developed for the implementation of the MB Faculty of Engineering Unimed curriculum is included in the appropriate category for use. According to Listiawan, the validation of educational experts was carried out with the aim of obtaining assessments, opinions, and suggestions on the suitability of the LMS product with the planned learning design or program $[5]$. 


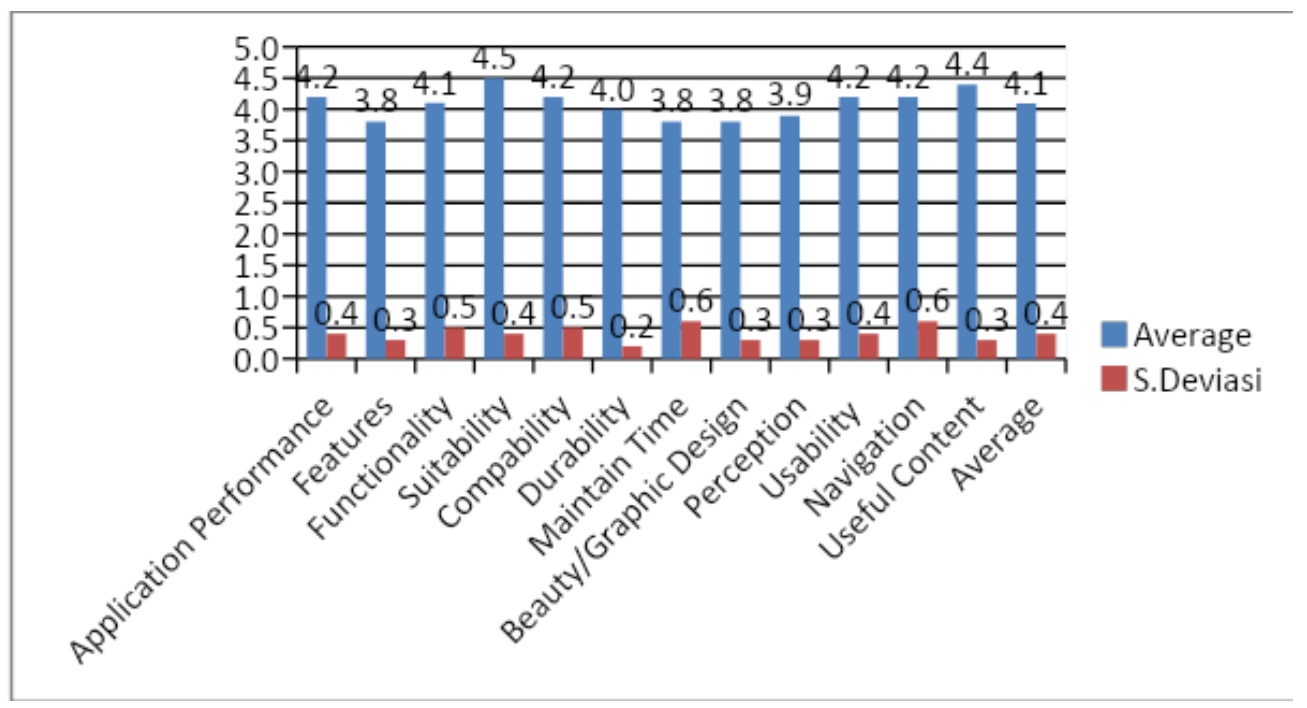

Fig. 5. Average and S. Deviation of LMS quality for the MB curriculum Faculty of Engineering Unimed.

The quality of a research product can be assessed based on the right indicators. Akbar stated that there are 12 indicators that can be used in assessing the quality of a learning management system [6]. Based on these indicators, it is used to assess the LMS quality of the MB Faculty of Engineering Unimed curriculum. The results of the LMS validation analysis of the Faculty of Engineering Unimed MB curriculum are presented in Figure 5. The results of the analysis show that of the 12 aspects of the assessment, it is found that the highest suitability aspect with a score of 4.5 with a standard deviation of 04 from the LMS Faculty of Engineering Unimed MB curriculum. Based on data obtained from experts regarding the quality of the LMS developed, the lowest score is found in aspects of features, maintain time and beauty or graphic design with an average score of 3.8. Overall, the LMS quality of the MB Faculty of Engineering Unimed curriculum was obtained with an average of 4.1 with a standard deviation of 0.4 . Based on the results of the validation about the appearance of the LMS, the MB curriculum can be categorized as suitable for use in learning. By using the LMS learning curriculum MB Faculty of Engineering Unimed can facilitate the implementation of 8 types of merdeka belajar activities at Faculty of Engineering Unimed. Through the LMS, the MB Faculty of Engineering Unimed curriculum can make it easier for students to exercise their rights in applying merdeka belajar through participating in several activities offered at the LMS.

\section{Conclusion}

The process of developing an merdeka belajar curriculum model for Faculty of Engineering Unimed was carried out starting with problem analysis and developing an merdeka belajar curriculum for Faculty of Engineering Unimed consisting of 8 types of learning activities, namely: 1) internship/work practice; 2) Thematic Community Service Program; 3) humanitarian projects; 4) entrepreneurial activities; 5) independent study/project; 
6) research; 7) student exchange; and (8) teaching in schools. Students are given the right to do lectures for 3 semesters outside the study program by choosing several merdeka belajar activities. The development of an merdeka belajar curriculum model in the form of a learning management system (LMS) at Faculty of Engineering Unimed to make it easier for Faculty of Engineering students to fulfill the right to carry out merdeka belajar. LMS provides guidelines and systems that are carried out in participating in 8 types of lecture activities outside the study program. The results of developing the LMS curriculum for merdeka belajar at Faculty of Engineering Unimed based on expert validation of the material and LMS design have been suitable for students to use. With the LMS, the merdeka belajar curriculum is a means for Faculty of Engineering Unimed students to carry out merdeka belajar which in turn can improve the competence of Faculty of Engineering Unimed graduates.

\section{References}

[1] Sesfao M. Perbandingan Pemikiran Pendidikan Paulo Freire Dengan Ajaran Tamansiswa Dalam Implementasi Merdeka Belajar. Pros. Semin. Nas. 2020; 261-272.

[2] Dewantara KH. Pemikiran, konsepsi, keteladanan, sikapmerdeka, I (Pendidikan). Yogyakarta: UST Press; 2013.

[3] Sugiyono. Metode PenelitianKulantitatif, Kualitatif, dan R\&D. Bandung: Alfa Beta; 2014.

[4] Borg WR, Gall MD. Educational researcher: An introduction. 7th. United States: Pearson education, Inc; 1983.

[5] T. Listiawan. Pengembangan Learning Management System (Lms) Di Program Studi Pendidikan Matematika Stkip Pgri Tulungagung. JIPI (Jurnal Ilm. Penelit. dan Pembelajaran Inform. 2016; 1 (1): 14-22.

[6] Akbar RI. Pengembangan Instrumen Penilaian LMS menggunakan Importance Performance Analysis Matrix. Format J. Ilm. Tek. Inform. 2021; 9 (2): 136. 